Medical Society of London and in the keeping of the society's learned and courteous librarian, Mr. George Bethell.

I am, Sir, yours faithfully,

S. D. Clippingdale, M.D. Aberd.

Holland Park-avenue, W., April 23rd, 1916.

\section{THE WITTENBERG CAMP.}

To the Editor of THE LANOET.

SIR,--Psychology in relation to the war has been prominent in your columns of late. In connexion therewith the letter of Sir William Milligan is of considerable interest. The natural indignation and horror at the Wittenberg atrocities will, of course, be shared by every decent human being in the world. It is perfectly certain that if the faots were allowed to be known by them a large proportion of German doctors would repudiate the action of Aschenbach with shame and loathing. Does Sir William Milligan really think that all our confrères in Germany, who have been welcomed and honoured in this country, have suddenly become "beasts"? The idea is unthinkable and absurd. To pass such a wholesale condemnation upon them as Sir William Milligan suggests would be hasty, undignified, and on a moral and intellectual level with the banishment of German music from our shores. When the passions of the present time have disappeared no one will regret more than Sir William Milligan himself the ill-considered proposal he is now making. - I am, Sir, yours faithfully,

Finchley, April 23rd, 1916.

J. S. BOOTHROYD, M.D.

\section{(Bbituatu.}

JAMES HARPER, M.D. LOND., M.R.C.S.,

COLONEL AND ASSISTANT DIRECTOR OF MEDICAL SERVICES, 1ST LONDON DIVISION (T.F.)

We have already recorded the death of Dr. James Harper, which occurred on March 24th. He was born at Leith in 1857, but his father, a medical practitioner, very shortly afterwards moved to Windsor, where Dr. Harper's boyhood was spent. He was educated at Amersham Hall School, Reading, and having matriculated at the University of London he entered as a student at St. Bartholomew's Hospital. His career at "Bart.'s" was very successful. He passed his medical examinations with ease, took honours in obstetric medicine at the Final M.B. Examination, and in 1883 graduated as M.D. Lond. He filled the office of house surgeon at St. Bartholomew's Hospital and afterwards was successively house physician to the Royal Hospital for Diseases of the Chest, and resident medical officer and anæsthetist to the Hospital for Women, Chelsea. Having thus fitted himself for practice he took a house in South Kensington and quickly gathered about him a large practice.

But Dr. Harper's activities were not limited by the demands of his practice, and for many years he devoted a good deal of time to the Medical Corps of the Volunteers. Joining the Volunteer Medical Service Corps in 1894 he in due course became captain, major, and then lieutenant-colonel in that force. In April, 1908, he was appointed to the 3rd London Field Ambulance, and in 1912 was promoted to the rank of colonel and made A.D.M.S., 1st London Division. He was intensely interested in his military duties and threw himself into the work of training his ambulance units with great enthusiasm and success. At the outbreak of the war he laid aside his practice and devoted himself wholly to his work as A.D.M.S., and he only gave up this work when he was a broken man, too ill to do it.

One who knew him well writes:- "His great ability and industry were associated with such a robustness of character and also such a merry humour that all who knew him were drawn to him and were helped by his example. In his private practice his patients highly valued him, for his medical knowledge and experience were combined with such kindliness of heart and strong commonsense that they found him to be not only a wise medical adviser but a strong and true friend. The high esteem in which he was held was strikingly shown by the large gathering of mourners who attended his funeral service. Harper was a man of fine presence, and in his physical vigour as well as in his strength of character, tempered by a deeply religious spirit, he showed the influence of his Scottish parentage. About four years ago he underwent a serious operation, and although he recovered and resumed his practice his work afterwards was often carried out under difficulty. Early this year signs of increasing illness showed themselves, and in spite of rest and the efforts of trusted and attached medical friends, his weakness increased and he passed away on March 24th. None who ever knew James Harper will forget him, for his high standards and strength of character made him a marked man."

Dr. Harper was twice married, first to Helen Watson Brand, daughter of the late Alexander Brand, United States Consul, Aberdeen, and later to Annette Ellen Grant, youngest daughter of the late Admiral Henry Duncan Grant, C.B. He left three sons and two daughters, and one son was lost in the explosion on the Princess Irene.

CORNELIUS HANBURY, M.R.C.S., L.S.A., F.C.S., F.I.C., CHAIRMAN OF THE BOARD OF DIRECTORS OF ALLEN AND HANBURYS, LIMITED.

Mr. Cornelius Hanbury, of the Manor House, Little Berkhampstead, died on April 11th, aged 88, having been born on Nov. 29th, 1827. He was the only son of Cornelius Hanbury, of Plough-court (who died in 1869), and his second wife, Elizabeth, daughter of John Sanderson of Avonthorpe and cousin of the present Lord Sanderson. Mrs. Cornelius Hanbury was well known for her Christian and philanthropic work in connexion with the cause of antislavery and the prison reforms of Elizabeth Fry, dying in 1901 at the remarkable age of 108 . Both Mr. and Mrs. Cornelius Hanbury were members of the Society of Friends and ministers in the society. Mr. Cornelius Hanbury, the son, after education under a private tutor became a student at St. Bartholomew's Hospital. From 1845 to 1850 he was apprenticed to Dr. (afterwards Bishop) Henry Callaway, and lived with him in Bishopsgate-street for about a year. In 1849 he became M.R.C.S., and in 1850 L.S.A. In 1876 he was elected treasurer of the Pharmaceutical Society, but resigned this office in 1878. He was a member of the council of the society from 1875 to 1878 . In 1871 he was nominated a governor of St. Bartholomew's Hospital and for some years held the office of almoner. Towards the end of 1849 Mr. Cornelius Hanbury first began to attend daily at the pharmacy at Plough-court, then under the control of his uncle, Daniel Bell Hanbury, and his father, Cornelius Hanbury, senior. There he became intimately associated with his cousin, Daniel Hanbury, F.R.S., who made some important scientific contributions to materia medica.

In 1868, with the retirement of Daniel Bell Hanbury and Cornelius Hanbury, senior, the two cousins became the acting partners of the firm. On the retirement of Daniel Hanbury in 1870, Cornelius Hanbury became proprietor of the business. A comparatively young man, he had the sole control of a well-appointed and established business, which, starting in the hands of Sylvanus Bevan in 1715, had grown up with the sound traditions laid down by its founder. A generation of Hanbury control had preserved the same traditions. Mr. Cornelius Hanbury, while maintaining the same ideals, looked far ahead and realised the possibilities of specially developing the wholesale and manufacturing lines of the firm. Years of foresighted expenditure and gradual expansion have followed, resulting in the many undertakings and branch establishments of this firm not only in this country but in various parts of the world. Cornelius Hanbury combined strength of purpose with the utmost simplicity. His life and example were an inspiration to all those with whom he came in contact, and the news of his death will be felt, not only by those at home, but by a great number of the firm's employees now serving at the front. The general affection and respect of the firm's employees towards the chairman were shown in 1896, when the staff presented Mr. Cornelius Hanbury with a portrait of himself painted by $\mathrm{Mr}$. Percy Bigland. He married in 1850 Sarah Jane, daughter of Frederick Janson, of Lloyds and Stoke Newington. She died in 1903. His elder and only surviving son, Frederick Janson Hanbury, F.L.S., now to become chairman of the board of directors, was born at Stoke Newington on May 27th, 1851. Though born and brought up as members of the Society of Friends, both Mr. Cornelius Hanbury and his wife and children joined the Church of England. The interment took place at Highgate cemetery on April 14th, the funeral service having been held at St. Andrew's, Little Berkhampstead. 